\title{
Pesticide Container Rinsing 1
}

\author{
Thomas W. Dean, O. Norman Nesheim, and Fred Fishel ${ }^{2}$
}

This document explains what procedures are involved in creating a legally empty container.

\section{A Legally Empty Container}

The containers of some commonly used pesticides are classified as hazardous wastes if not propersly rinsed, and as such, are subject to the many rules and regulations governing hazardous waste. Improper disposal of a hazardous waste can result in very high fines and/or criminal penalties. However, pesticide containers that have been properly rinsed can be handled and disposed of as non-hazardous solid waste. Both federal law (FIFRA) and the Florida Pesticide Law (Chapter 487 F.S.) require pesticide applicators to rinse all "empty" pesticide containers before taking other container disposal steps. Under federal law (RCRA), A PESTICIDE CONTAINER IS NOT "EMPTY" UNTIL IT HAS BEEN PROPERLY RINSED. For more information, see the UF/IFAS publication Florida Solid and Hazardous Waste Regulation Handbook: Table of Contents (http://edis.ifas.ufl.edu/fe440).

\section{Rinsing Pesticide Containers}

Immediate and proper rinsing removes more than 99\% of the container residues typically left by most pesticide formulations. Properly rinsed pesticide containers pose minimal risk for contamination of soil and water resources. Preventing contamination is an important part of pesticide management.

Pesticide containers should be rinsed as soon as they are empty; thus, the time to rinse is during the mixing and loading process. Immediate rinsing has several advantages. A freshly emptied container is easier to clean because the formulation residues have not had time to dry and cake on the inside of the container. Also, rinsing containers during the mixing and loading process solves the problem of what to do with container rinse water as it is used to contribute to the water used to prepare the finished spray mix.

Newly emptied pesticide containers can be properly rinsed by either of two methods: triple-rinsing or pressure-rinsing - both will work.

1. This document is PI-3, one of a series of the Pesticide Information Office, Florida Cooperative Extension Service, Institute of Food and Agricultural Sciences, University of Florida. Revised May, 2005. Visit the EDIS Web Site at http://edis.ifas.ufl.edu.

2. Thomas W. Dean, Ph.D., assistant extension specialist, Pesticide Information Office and Food Science and Human Nutrition Department; O. Norman Nesheim, Ph.D., professor emeritus, Pesticide Information Office and Food Science and Human Nutrition Department, Frederick M. Fishel, Associate Professor, Agronomy Department, and Director, Pesticide Information Office; Florida Cooperative Extension Service, Institute of Food and Agricultural Sciences, University of Florida, Gainesville, FL 32611-0710.

Use pesticides safely. Read and follow directions on the manufacturer's label.

The Institute of Food and Agricultural Sciences (IFAS) is an Equal Opportunity Institution authorized to provide research, educational information and other services only to individuals and institutions that function with non-discrimination with respect to race, creed, color, religion, age, disability, sex, sexual orientation, marital status, national origin, political opinions or affiliations. U.S. Department of Agriculture, Cooperative Extension Service, University of Florida, IFAS, Florida A. \& M. University Cooperative Extension Program, and Boards of County Commissioners Cooperating. Larry Arrington, Dean 


\section{Triple-Rinsing a Container}

1. Put on the personal protective equipment listed on the product's label.

2. Allow formulation to drip drain from its container into the sprayer's tank for at least 30 seconds.

3. Partially fill container with clean water (about $20 \%$ of its capacity).

4. With the container cap placed back on, swirl the water so that all sides are rinsed.

5. Pour the rinse water back into the sprayer's tank and allow the container to drip drain for at least 30 seconds.

6. Repeat steps 2 through 5 twice more.

\section{Pressure-Rinsing a Container}

1. Put on the personal protective equipment listed on the product's label.

2. Install pressure-rinse nozzle on hose connected to a water supply capable of delivering 35-60 psi of water pressure.

3. Allow formulation to drip drain from its container into the sprayer's tank for at least 30 seconds.

4. Firmly press the pressure-rinse nozzle tip into the side of the pesticide container until the probe is inserted and seated, then turn on and rinse the container for at least 30 seconds with it draining into the sprayer's tank. For containers that are larger than 5 gallons, insert the pressure-rinse nozzle into its bottom.

5. Allow the container to drip drain for at least 30 seconds.

\section{Pressure Rinse Nozzles}

There are several styles of pressure-rinse nozzles commercially available. Most have a pointed nozzle tip with small holes set at 90-degree angles around the shaft. They attach to a standard garden hose.

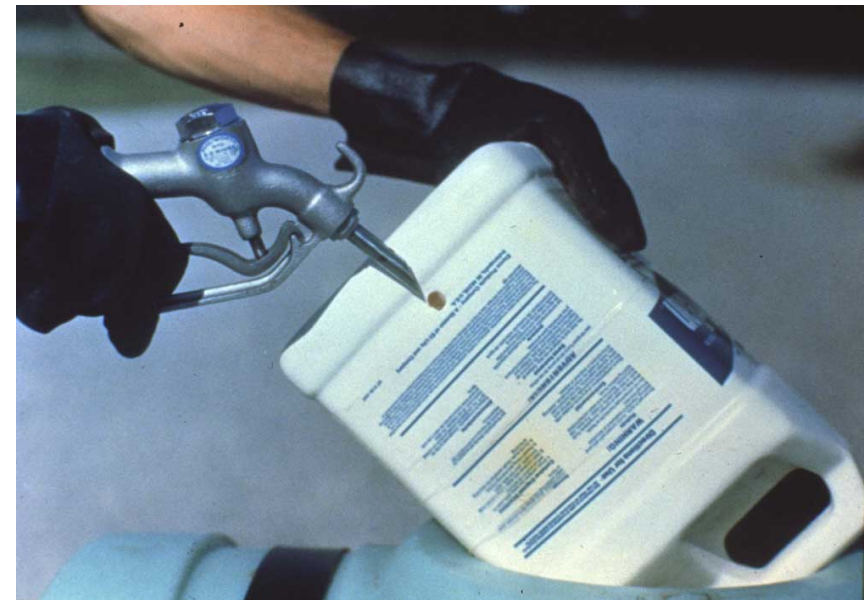

Figure 1. Pressure-rinsing a pesticide container.

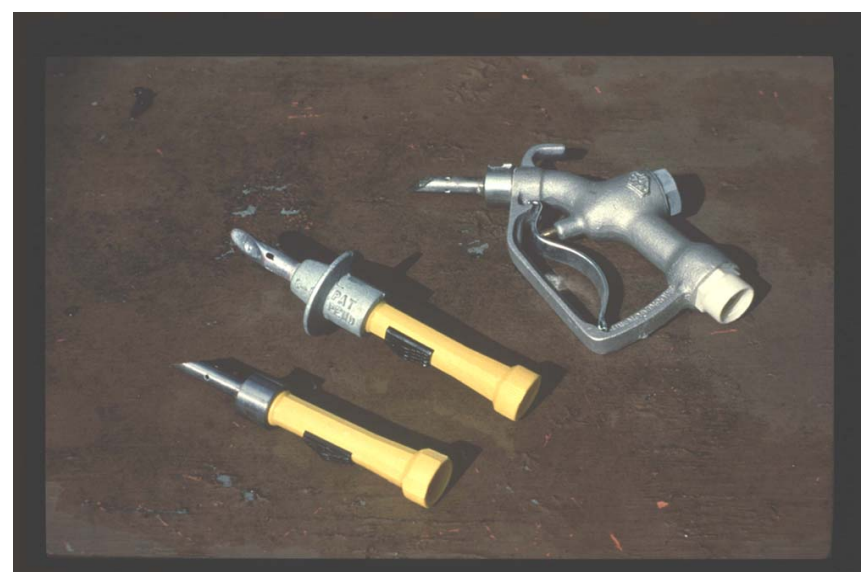

Figure 2. Varieties of pressure rinse nozzles.

\section{Additional Information}

Proper Disposal of Pesticide Wastes, IFAS

Factsheet PI-18, August 2000; Florida

Cooperative Extension Service.

(http://edis.ifas.ufl.edu/pi010)

Federal Insecticide, Fungicide, and Rodenticide Act (FIFRA) 7 U.S.C. s/s 136 et seq. (1996) http://www.epa.gov/region5/defs/html/fifra.htm. Visited May 16, 2005.

Florida Pesticide Law (F.S. 487.011-487.175) http://www.flsenate.gov/Statutes/ Visited May $16,2005$.

Resource Conservation and Recovery Act (RCRA) Online http://www.epa.gov/rcraonline/. Visited May 16, 2005. 